\title{
Pedagogical residency and teacher training: critical appointments about training programmes as means of social policy
}

\author{
Robert Sternberg ${ }^{1}$
}

\begin{abstract}
The objective of this research is to analyze the Pedagogical Residence Program instituted by the Brazilian Federal Government as a social policy, in order to point out contributions and setbacks in relation to its implementation in Brazilian federal universities. By means of a bibliographic survey, it is qualitative approach reasearch and it uses the critical theoretical references based on the discussions of Nóvoa, Contreras, Marcelo Garcia, Mellouki and Gauthier to support the analysis related to the understanding of teacher education and public policy social programs. We use notes from Antonio Nóvoa (2009) to think about the creation of a teacher training program considering the contemporary challenges. Studies show the need to redefine the pedagogical residence program so that we can advance in favor of a larger project for teacher education in Brazil.
\end{abstract}

Keywords: Pedagogical residence. Teacher training. Social policies for teaching. Teacher Training Programs.

Residência pedagógica e formação de professores: apontamentos críticos sobre os programas de formação como meio de política social

\section{RESUMO}

O objetivo desta pesquisa é analisar o Programa de Residência Pedagógica instituído pelo Governo Federal Brasileiro como política social, a fim de apontar contribuições e retrocessos em relação à sua

\footnotetext{
${ }^{1}$ Robert J. Sternberg, é um psicólogo e psicometrista estadunidense, deão de Artes e Ciências da Tufts University. Foi professor de psicologia na Yale University e presidente da American Psychological Association. Orcid: https://orcid.org/0000-0001-7191-5169.E-mail: ris54@ cornell.edu.
} 
implantação nas universidades federais brasileiras. Por meio de levantamento bibliográfico, trata-se de pesquisa de abordagem qualitativa e utiliza referenciais teóricos críticos baseados nas discussões de Nóvoa, Contreras, Marcelo Garcia, Mellouki e Gauthier para subsidiar análises relacionadas à compreensão da formação de professores e programas sociais de políticas públicas. . Utilizamos notas de Antonio Nóvoa (2009) para pensar a criação de um programa de formação de professores considerando os desafios contemporâneos. Estudos mostram a necessidade de redefinir o programa de residência pedagógica para que possamos avançar em prol de um projeto maior de formação de professores no Brasil.

Palavras-chave: Residência Pedagógica. Formação de professor. Políticas sociais de Ensino. Programas de formação de professores.

Residencia pedagógica y formación del profesorado: citas críticas sobre los programas de formación como medio de política social

\section{RESUMEN}

El objetivo de esta investigación es analizar el Programa de Residencia Pedagógica instituido por el Gobierno Federal de Brasil como política social, con el fin de señalar contribuciones y retrocesos en relación a su implementación en las universidades federales brasileñas. Mediante un relevamiento bibliográfico, es una investigación de enfoque cualitativo y utiliza los referentes teóricos críticos basados en las discusiones de Nóvoa, Contreras, Marcelo García, Mellouki y Gauthier para apoyar el análisis relacionado con la comprensión de la formación docente y los programas sociales de políticas públicas. . Utilizamos notas de Antonio Nóvoa (2009) para pensar en la creación de un programa de formación docente considerando los desafíos contemporáneos. Los estudios muestran la necesidad de redefinir el programa de residencia pedagógica para que podamos avanzar a favor de un proyecto más amplio de formación docente en Brasil.

Keywords: Residencia Pedagógica. Formación de profesores. Políticas sociales para la docencia. Programas de formación de profesores.

$$
* * *
$$




\section{Introduction}

Brazil's Education policy has, in its trajectory, turned us to important reflections in relation to the "National Policy for Basic School Teachers Education". The complex understanding of what it means to form teachers and address their real and multiple needs translates into actions proposed by the Federal government in order to make social policies feasible in a project that reveals concepts of a Government Plan. Projects that signal both technical or emancipatory concepts, principles that will appear in the legal and pedagogical framework to be established.

In the field of knowledge that deepens the theoretical dialogues about teacher training, we can witness a diversity of understandings that range from the conception linked to the training of teaching skills, to conceptions that translate into reflective actions that do not conform with pre-established standards and formats, but with actions that are born from a pedagogical practice based on a conscious and reflective praxis.

To enlighten the object of this research, the article will present three different discussions. The first will bring the critical perspectives of theoretical approaches by authors that deal with teacher education and its importance in the central context of a public policy that, in fact, assumes Education as a principle that should operate with quality, considering that its permanent subjects, the teachers themselves, should receive training from real, plentiful contexts and in multiple learning spaces.

The second discussion will guide the Pedagogical Residency Program seeking to bring some characteristics of this important proposal to light, in order to analyze its developments. And in the third discussion, the text will bring theoretical outlines to make us think about programs for teacher training, in order to affirm the importance of the institutionalization of Public Policies in a critical and emancipatory perspective. 


\section{Critical perspectives of Teacher training.}

In the field of teacher training, it has been some time ever since critical perspectives have been welcomed and allowed the construction of analyses that go beyond the approach of teaching as a mere technicalinstrumental task.

However, there is still an array of prerogatives that postulate the need for the existence of initial teacher training courses to be more practical and less theoretical. In spite of, in fact, the need for curricular transformation and, therefore, a new design of these courses, it is not possible to think of an initial training that presents almost exclusively practical outlines. And it is in this sense that the critical perspectives make a contribution to the area, since this defense of a more practical course is sheltered, in its core, by the assumption of a return to a technical approach, which has already proved to be insufficient for the comprehension of teacher education.

This is also supported by the empirical data collected on research on these topics that favor a considerable distinction between practical and academic intelligence, for it was noticed that the exercise of practical intelligence increments significantly the possibility of success in all the careers investigated - including teaching (STERNBERG, 2001).

At a cognitive level, this is explainable by the fact that intelligence is not a 100\% biological (STERNBERG, 2019), which could also be closely linked with cultural aspects and other variables of the life of the individual at observation. Sternberg also argues that human intelligence is adaptable, and tha this adaptability, which is different from the general, plain IQ cognitive ability in itself. It is more than that.

And Sternberg (2019) goes further than just mere genes adaption to the surrounding environment, but it also involves an individual's ability to adapt to its surroundings, meaning that no concept of intelligence or even learning could ever be universal. In this sense, for example, the tests applied 
to a class of students in different cultural settings needs to be different in order to accurately measure their learning ability. This is precious information, since practice if often underrated in pedagogical training.

Human beings, as inserted in an economic and social setting, also bear the brain ability of "plasticity" (STERNBERG; ELLIS; et al, 2020), meaning that the human mind is adaptable to unpredictable environments, which could lead to a development of ones hidden talents. Intelligence varies over space and time, reflecting its means to adapt to the challenges posed by each new situation, placing pedagogical practice in a very important position in a modern, ever-changing globalized society.

One good example of how academic research information detached from practice on education can negatively affect the practice of teachers is what could happen in low-income communities, if they get in contact with biased research that demonstrate that communities with low-income and a historic of adverse experiences have deleterious effect on early-cognitive capacity, arriving at such communities with these pre-conceived perceptions of the students, due to their lifelong exposure to stress, violence, or any adverse situations. This does not favor a "growth based minset" (STERNBERG; ELLIS; et al, 2020).

In this sense, it is due to the epistemology of practice - anchored in John Dewey and systematized, among others, by Donald Schön - the recognition that initial training courses make up just one more element in the long process of professional learning in the teaching career; a lifelong learning, that starts long before initial training. If before, in a technical approach, courses were understood as the moment par excellence for teacher training, today, it is known, as Marcelo García (1999) suggests, for example, that they make up the second stage of a long process. The approach to teacher training implies recognizing that it is carried out, at least, in four complementary stages, namely: pretraining, initial training, initiation to teaching and continued learning. 
The perspective of practical rationality - although it cannot be called critical, here - makes it imperative to recognize that it is necessary to work in the personal dimension of the teacher. When we discuss, for example, the construction of teaching knowledge in an attempt to understand which different sources teachers use to learn how to be a teacher, it is recognized that, as advocated by Nóvoa (1992), the teacher is also an important part of the person. In other words, it is an idiosyncratic process and, as such, it recognizes that each subject in training finds different sources of knowledge, has different life stories, seeks teaching for different reasons and all these factors are strong markers of the process of building a professional identity.

Due to the advent of the epistemology of practice, there is a greater concern with a broader formation of teachers. This is because, contrary to what the technical approach proclaims, being a teacher is not limited to initial training courses, but it is a process that is revealed, made and remade in the daily life of schools. In other words, there is an acknowledgment that real teachers training is only effective in the daily life of the profession within its space, in the day-to-day of the classroom, a fact that does not invalidate the initial training process, but, on the contrary, places it within possible outlines.

It is necessary to affirm, then, that the epistemology of practice brings about a turning point in the way of conceiving teacher education. Initial training becomes just another moment in a long process, a fact that does not diminish its need and relevance, but allows it to give specific outlines within its reach. However, even though the practice aspect is hegemonic in the discussions in the area, the critical perspectives seek to consolidate other perspectives on this discussion.

Considering the importance of critical perspectives for teacher training, they emphasize the importance of initial training and seek to match the reflections of the training paths to those elements that go beyond the walls of school education. In other words, teacher education is recognized as a locus that suffers direct influences and interferences from 
the political context in which it is inserted. Without neglecting the assumptions of the epistemology of practice, what the critical perspectives seek to bring to the debate is that this formative route cannot be limited to analyses of strictly pedagogical practice; it goes beyond it.

In this sense, the critical perspective attempts to connect the initial training courses to the possibilities of building another society. According to Contreras (2002):

And teachers are seen as 'transformative intellectuals', as it is not just a commitment to the transmission of critical knowledge, but to social transformation itself, through training to think and act critically. (CONTRERAS, 2002, p. 159)

There is no disregard for the domain of scientific knowledge and technical skills, nor is it less important for the personal, idiosyncratic path of each teacher. Instead, critical perspectives seek to broaden the scope of understanding these elements beyond the daily pedagogical practice. It is necessary to recognize that the initial training of teachers is understood beyond the domain of methods and techniques, passing through the possibilities of contribution to social transformation.

Mellouki and Gauthier (2004) call attention to the complexity of being a teacher, as this profession is directly linked to what they call a "mandate of heir, interpreter and critic". Each teacher acts in a constant process of reproduction of the knowledge that was taught to him or her, of the life and training experiences to which he or she was submitted, but he or she might also recreate, in a singular way, these situations in his or her pedagogical practice.

This said, it is possible to affirm that the public policies that allow thinking about the training and the teaching profession still need to move in the direction of recognizing this continuous process of professional learning and of how this process requires, in its midst, a recognized critical subject and, as corollary to this, a participative and active subject. For Contreras (2002), a critical teacher with a transformative potential is one capable of: 
[...] elaborating both a critique of working conditions and a language of possibilities that open up to the construction of a more just and democratic society, educating its students as critical and active citizens, committed to the construction of an individual and public life worthy of being lived, guided by the principles of solidarity and hope. (CONTRERAS, 2002, p. 161).

It is necessary to recognize that the public policies proposed for the training of teachers also need to be subjected to the scrutiny of those who are experiencing it. This is because, through these daily views, it is possible to point out the elements that need to be improved. In a critical perspective, there is no public policy that is conceived outside the active participation of the subjects involved, that is, even though teachers in training have been excluded from their formulation, they cannot continue to be excluded from the analyses of the evaluations and implementations of these policies.

\section{Pedagogical Residency Training}

The history of the Pedagogical Residency has a path that takes us back to 2007, when a proposal for Residential Education was discussed on the occasion by Senator Marco Maciel who stated that his ideas were born from the Medical Residency Program. Through the Project of Senate Bill no. $227 / 07$, the legal proposal would enable 800 hours of minimum workload, a training modality that happens after the initial training, however this Senate project did not advance in the discussions at the Brazilian National Congress and there were doubts about the budgetary aspects of financing of scholarships for "resident" teachers.

In 2012, this same project returns to the Senate by Senator Blairo Maggi who reformulates and changes the name of Educational Residency to Pedagogical Residency, providing the same 800 hours of workload and scholarships for teachers. The process would be after the initial training, 
and in this new reformulation, the participation in the project would not be a prerequisite for the candidate to work in basic education, but it could be considered as an additional certification in civil service examinations, and teachers already working could also benefit from it.

In 2014, Bill Project no. 06/2014, by Senator Ricardo Ferraço, proposed changing the name to "Teaching Residency". It would be an extra step for the training of teachers, with a total workload of at least 1600 hours, divided into two stages, the offer should be made to undergraduate students with a maximum of three years of graduation and the monitoring would be done by professionals working in the same network as the teacher was working. The implementation of the Bill did not occur due to numerous unfavorable points and lack of dialogue with the teachers' representative entities.

Teacher professionalization, a concept that arises from important insights to think about teacher education, whether in its initial or continuous career, requires theoretical methodological positions that understand the teaching profession in its complex, reflective and emancipatory perspective.

In 2018, through Notice 06/2018 from the Brazilian Coordination for the Improvement of Higher Education Personnel (CAPES), for Pedagogical Residency:

The pedagogical residency consists of the planned and systematic immersion of the undergraduate student in a school environment, aiming at the experience and experimentation of concrete situations in the school routine and in the classroom, which will later serve as an object of reflection on the articulation between theory and practice. During and after immersion, the resident should be encouraged to reflect and evaluate his/her practice and relationship with the professionalization of the school teacher, to register in a report and to contribute to the socialization of the evaluation of his/her experience as a resident. (Edital CAPES 06/2018) 
Comprehending teacher training without dichotomies between practical and theoretical aspects of training and also establishing the importance of considering the construction of forming actions in initial training, and encompassing the first stage of the teaching career, we affirm the importance of the continuity of institutional responsibility with these permanent subjects of the Brazilian educational process, the teachers themselves.

Nóvoa (2009) argues that the initial training establishes the Universities as a place of ideas and practices that he calls the "common home", where professional actions are established based on a specific logic of the teaching career and that contribute to thinking about the challenges at the beginning of the career, while being accompanied by teams of teachers, researchers and managers, in order to establish dialogues based on the construction of autonomous pedagogical practices in a real context that points out paths in favor of these complex processes that are teaching and learning, that result in experiences.

The experience is configured in the strengthening of the search for discovery intertwined with legitimate teaching pedagogical practices and managed in real spheres in the learning space; the movement of discovery propels the teacher to study and improve actions, in a context of ongoing training in his/herprofessional career. (ABREU SOUZA, 2011, p: 83)

The experience invested in the teaching practice reveals the singular actions of this future teacher and requires training programs that guarantee such diversity, considering the daily life of the educational process.

We believe that the Pedagogical Residency, as provided for by the Capes Notice no. 06/2018, directs us to:

- A reduced version of the project that shows a conception that recognizes the practice in an induction process, through the reformulations of the internship and also reduces the workload of practice compared to the model that preceded the Pedagogical Residency program. It establishes a dichotomy between practice and theory: 
In our view, such a perspective incurs in a reductionist view of teacher training, which instead of implementing the necessary theory-practice unit in the formation process, which cannot be dichotomized, proposes a definitive disconnection from theory and practice, reducing teacher training to a "how to do", uncompromising with a socio-historical and emancipatory view of teaching. This undermines the quality of basic education for Brazilian children and young people, depriving it of its social and politically oriented function (Nota das Entidades, 2018)

- Centralizing character of the program's actions aimed at government control and reducing the autonomy of universities in relation to establishing specific possibilities of different realities.

We emphasize that linking the Pedagogical Residency Program to the National Common Curricular Base (BNCC) damages university autonomy, by inducing institutional training projects in Higher Education Institutions (IES) that disagree with the concepts of teacher training present in their own pedagogical projects, violating the recommended both in the Opinion and in the Resolution from CNE/CP no. 2/2015, which define the National Curriculum Guidelines for Initial and Continuing Teacher Education in Brazil (Nota das Entidades, 2018).

- Conception of scholarship is based on principles of assistance, which distances this construction from approaches that truly strengthen concepts that could validate teaching as a profession with a specific performance logic.

The discourse of the Ministry of Education / Capes that celebrates the synergy between school and university covers the fact that the Pedagogical Residency Program is an attempt to deconstruct initial training projects committed to teaching as an intellectual and creative activity. This has profoundly deprofessionalizing effects in undergraduate courses (...) (Nota das Entidades, 2018) 
- Induction of actions focusing on the National Common Curricular Base (BNCC), a document that emerges without considering the notes of large-scale research institutions.

We repudiate any association of these programs with the National Common Curricular Base (BNCC), characterized by narrowing the curriculum and whose process of elaboration, discussion and approval has been the target of strong criticism from academic and scientific entities since 2015. Our rejection and concern are due to several reasons, of which we highlight the first two: the immediate connection of the National Common Curricular Base (BNCC) with the large scale assessments, given the codified structure that marks the writing of this document, already focused on the quantification and standardization of future tests; and the induction, in the case of secondary education, of privileging only two school subjects, as recently announced, with a view to adapting the Common National Curricular Base (BNCC) to exams such as the Programme for International Student Assessment (PISA) (Nota das Entidades, 2018)

The entities that sign this note: National Association of Graduate Studies and Research in Education (ANPEd), National Association for the Education of Professional Educators (ANFOPE), National Confederation of Education Workers (CNTE), National Forum of Directors of Colleges, Institutes, Education Centers or Equivalents of Brazilian Public Universities (FORUMDIR), National Association of Educational Policy and Administration (ANPAE), Brazilian Curriculum Association (ABdC), Education and Society Studies Center (CEDES), National Association for Research in Financing Education (FINEDUCA), National Campaign for the Right to Education, Action for Education, National Movement in Defense of High School Education (MNDEM), Public-School and University Network (REPU), Brazilian Association for Research in Science Education (ABRAPEC). 
Institutions' mobilizations point to a concern that directly impacts Brazilian policies on teacher training and results in setbacks in relation to the quality of education.

\section{Thinking about the Program / or a Program}

Nóvoa (2009), one of the researchers who has been most dedicated to the theme of teacher training in contemporary times, points out aspects necessary to understand the creation of a program for teacher training in a professional context.

It is possible to affirm that, in his article entitled "Towards teacher training built within the career", Nóvoa (2009) points out five propositions that can support the creation of Programs in a critical perspective of public policies for the initial training of undergraduate degrees.

The propositions start from key words: PRACTICES, PROFESSION, PERSON, SHARING, PUBLIC. We will comment below:

Practices Teacher training should have a strong praxic component, centered on student learning and the study of concrete cases, with school work as a reference. (NÓVOA, 2009, p.25-45.)

The programs, when created, need to come out of the dichotomy between theory and practice, and consider the dialectical concept from the understanding of praxis that shows us much more than practical tendencies or just content, but conceive the teaching knowledge in which the practice is conceived both in methodological and theoretical frameworks.

The construction of the pedagogical practice is established in a complex and demanding way, however, as stated by Nóvoa (2009), “(...) sometimes the idea that teaching is very simple is publicly fed, thus contributing to a discredit of the profession". The practice without theoretical subsidies is not created with quality, therefore the need for 
the programs shall comprehend a dialectical process in the formation coming from the praxis.

Profession Teacher training must move "into" the profession, that is, it must be based on the acquisition of a professional culture, giving more experienced teachers a central role in the training of younger professionals. (NÓVOA, 2009, p.25-45.)

That means to integrate training with a professional culture that can only be established coming from the profession. Nóvoa reminds us how doctors, engineers and architects are trained and shows us that we often have professors or teachers who are specialists in specific research. And this performance is important, but we need experienced teachers to train teachers. According to Nóvoa, it means to “(...) insist on the need to return teacher training back to the teachers, because the reinforcement of research-based training processes only makes sense if they are built within the profession” (Nóvoa, 2009, p. 45 ).

Nóvoa (2009) stands for the training phase and professional induction (first years of teaching), which must also comprehend teacher training programs in order to integrate and subsidize the countless challenges that arise from starting work in a professional career.

Person The training of teachers must pay special attention to the personal dimensions of the teaching profession, working on this capacity for relationship and communication that defines the pedagogical thoughtfulness. (NÓVOA, 2009, p.25-45.)

Nóvoa has, in his writings of recent years, repeatedly warned us that "the teacher is the person and that part of the person is the teacher". According to Nóvoa, the personal dimension is impossible to be separated from the professional dimension. The teaching work shows an aspect about itself, which points us to think about training actions of self-reflection and self-analysis, meaning that “(...) it is important to stimulate, together with 
future teachers and in the first years of professional practice self-training practices, moments that allow the construction of narratives about their own personal-professional life stories”. (Nóvoa, 2009, p.25)

Field diaries on planning and development of practices can include narratives about personal reflections that bring aspects based on the stories themselves.

Sharing The training of teachers must value teamwork and the collective exercise of the profession, reinforcing the importance of school educational projects (NÓVOA, 2009 , p.25-45).

The 21st century challenges teachers in a reality in which the collectivity is established at the professional level. A teacher training program needs to go beyond adding individual knowledge and expertise. Novoa tells us about the “(...) need for an enriched professional fabric, the need to integrate a set of collective modes of production and work regulation into the teaching culture” (NÓVOA, 2009, p.25-45)

Novoa reminds us of two aspects that encompass the purpose of sharing in teacher training: first, that the school should be seen as the space for training, for the shared analysis of practices, with the aim of transforming the collective experience into knowledge of the profession; and according to the collective idea of teaching, both in terms of knowledge and ethics.

Public Teacher training must be marked by a principle of social responsibility, favoring public communication and professional participation in the public space of education. (NÓVOA, 2009, p.25-45.)

Does the school communicate well with what is external to it? Does it explain its work well? Does it evaluate its own work? Do teachers participate in public debates? Nóvoa considers that the school needs to assume its specific space departing from its own place, so that communication must be established in a way that the space and role of the school in the contemporary world can be reframed. "Contemporaneity 
requires that we have the ability to recontextualize the school in its own place, valuing what is specifically from school (...)” (NÓVOA, 2009, p.25-45)

The five purposes that Nóvoa presents us should not be seen as standardized guidelines for the creation of Public Programs for Teacher Education, but as aspects to be reflected on so that we can go beyond standardized projects that serve the logic of the market and capital in a society in which training actions are made possible to privilege private groups and, thus, they leave the priority of establishing training, which is the qualification of teaching, at the expense of the profits that the training market makes possible.

\section{Final Considerations}

The present article was aimed to establish bibliographic notes on teacher training and education, understanding that such conception is necessary so that we can understand what underlies the perspectives that organize Public Programs with a focus on Teacher Education.

We brought the path of the Pedagogical Residence since 2007 in its legal aspects, so that we can understand the trajectory of the Program. Finally, we resumed the contributions of Antonio Nóvoa to bring reflections on: the practice, the profession, the person, the sharing and the public, about the necessary aspects for the creation of a Public Programme on Teacher Training.

We recognize the complexity that is required when proposing public policies on training, but the absence of dialogue with Associations, Institutions and Movements that are developing research and debating teacher education in Brazil is evident.

With regard to this aspect, it is necessary to point out that, just as they defend critical perspectives, teachers need to be recognized as active subjects and capable of formulating public policies on their own matters. Despite the relevance of the Pedagogical Residency Program, it is configured 
in yet another initiative aimed at the initial training of teachers, failing to conceive of this career as a continuous process of professional development. We still lack public policies capable of taking a broader look at the profession, that is, at one time, they are solely focused on initial training, and at another time, they are focused exclusively on the beginning of the teaching practice (which is still very incipient) and now, they tend to be only focusing on continued education (although not in a very systematic way).

As necessary as the policies that recognize the specificities of each stage of the learning and professional development process are, we still need policies that conceive these different stages as a continuous and integrated process. In other words, even though the Pedagogical Residency Program contributes to a greater insertion of the future teacher in his or her field of professional performance, in fact, when getting in contact with his or her career, the teacher continues to have to act and develop alone. It is urgent to build public policies that collaborate to alleviate the so-called reality shock, which does not yet seem to be the case with the program in question.

Today, we are asked questions in the context of a society that is changing and that asks for a new meaning for the school and, consequently, for the actions that train teachers to work at the school. This reframing requires, necessarily, the recognition of the teacher's role, as this professional needs to be invited to participate actively in the formulation of public policies that directly impact the organization and conception of his or her work. Only when teachers can perform this creative role and, in fact, formulate broader guidelines for the profession, will other possibilities be feasible to be designed for our educational system.

\section{Referências}

ABREU SOUZA, A.C.G. Formação de Professores: Da experiência do sujeito, ao sujeito da experiência. Tese de doutorado: PUC:SP. 2011.

BRASIL . Edital CAPES 06/2018 que dispõe sobre a Residência Pedagógica. https://capes.gov.br/images/stories/download/editais/01032018-Edital-62018-Residencia-pedagogica.pdf. Disponível em 27 de novembro de 2019. 
BRASIL. Senado Federal. Projeto de Lei $N^{o} 227$, de 2007 sobre a "residência educacional a professores da educação básica”, de autoria do Senador Marco Marciel. http://www25.senado.leg.br/web/atividade/materias/-/materia/80855. Disponível em 27 de novembro de 2019.

BRASIL. Senado Federal. Projeto de Lei $N^{\circ}$ 06, de 2014 que dispõe sobre a "residência pedagógica do Senador Ricardo Ferraço que altera a Lei 9394/ 96. Disponível em: https://www25.senado.leg.br/web/atividade/materias//materia/115998. Acesso em: 27 de novembro de 2019.

CONTRERAS, J. A autonomia de professores. São Paulo: Cortez, 2002.

MARCELO GARCÍA, C. Formação de professores: para uma mudança educativa. Porto - Portugal: Porto Editora, 1999.

MELLOUKI, M'hammed and GAUTHIER, Clermont. O professor e seu mandato de mediador, herdeiro, intérprete e crítico. Educação \&. Sociedade. 2004, vol.25, n.87, pp.537-571.

Notas das entidades em relação a Residência Pedagógica. Manifestação das entidades educacionais sobre a política de formação de professores anunciada pelo MEC. Disponível: http://www.anped.org.br/news/manifestacao-dasentidades-educacionais-sobrepolitica-de-formacao-de-professores-anunciada. Acesso em 27 de novembro de 2019.

NÓVOA, A. Os professores e a sua formação. Porto: Dom Quixote, 1992.

NÓVOA, A. Para uma formação de professores construída dentro da profissão. In: NÓVOA, A. Professores: Imagens do futuro presente. Lisboa: Educa: 2009, p.25-45.

STERNBERG, R. J. A theory of adaptive intelligence and its relation to general intelligence. Journal of Intelligence, v. 7, n. 4, p. 23, 2019.

STERNBERG, R. J.; ELLIS, B. J.; et al. Hidden talents in harsh environments. Development and Psychopathology, v. 1, p. 19, 2020.

STERNBERG, R. J.; NOKES, C.; et al. The relationship between academic and practical intelligence: A case study in Kenya. Intelligence, v. 29, n. 5, p. 401-418, 2001. 